\title{
Searching for the Essence of Architecture at Porto School
}

JOÃO PEDRO XAVIER - TERESA CALIX — FRANCISCA MESQUITA

Faculdade de Arquitectura da Universidade do Porto 
The Faculty of Architecture at the University of Porto (FAUP), founded in 1979, and benefiting from the legacy of the School of Fine Arts (ESBAP), is internationally recognized and a worldwide reference in architectural teaching. Important names of the 'School of Porto' studied and lectured at ESBAP and FAUP. Fernando Távora (1923-2005), Álvaro Siza (b. 1933) and Eduardo Souto de Moura (b. 1952) - the last two Pritzker Prize winners, among many other distinctions - might be considered the three pillars of the school, although their contribution cannot be considered without their predecessors, the group of people they worked with and the Portuguese particular context.

Located at University of Porto's Polo III (Campo Alegre), the complex of buildings housing FAUP, since 1992, is also one of the most emblematic creations in Álvaro Siza's career. Designed and built between 1985 and 1993, FAUP is composed by the socalled Casa Cor-de-Rosa (pink house), Cavalariças (old stables), and Carlos Ramos Pavilion, situated in Casa Cor-de-Rosa's garden, and several new Blocks at west. The whole complex hosts many Studios and Classrooms, Auditoriums, Research Center, Library, Documentation Center, Exhibition Gallery, Administrative Offices, Bookshop, and Cafeteria.

Both these masters' strong personalities - embodied in their pedagogical action - and the space where the didactics take place - actually a project by one of them - are omnipresent and might be considered the better 'not so hidden' secret of our School.

These three architects were linked in teaching practice, profession and life. They experienced a master/disciple relationship at a certain point, and later shared, as professors, a strong idea of School; Souto de Moura worked in Siza's office, and Siza in Távora's, and they made together several architectural works; most importantly, they became very good friends! At different stages they were responsible for Architectural Design Studios, Construction, and Theory and History courses. Nowadays, Souto de Moura is the only one still active at the school, being called to participate in juris, conferences, seminars, advanced courses, and in a new Ph.D. optional course related to Theory and Architectural Design Practices. Anyhow, Siza is often called to participate in some classes, and any conference he addresses at the School, which still happens periodically, has a guaranteed full house.

The majority of the current teachers had the opportunity to have them as professors. Perhaps the most lasting influence in the school was Távora's, who was responsible for the firstyear course General Theory of Space Organization, to which we all attended. Then, after Távora's jubilation the course was continued by Siza together with Beatriz Madureira (1940-2017), 
Távora's assistant. After Siza's jubilation the course was reinterpreted and transformed by Manuel Graça Dias (1953-2019).

Basically, Távora and Siza introduced the students to the essence of architecture, anchored on its Vitruvian foundation, transmitting the belief in space as the main material of architecture, and taking in consideration its cultural, social and political dimensions. Theory and History fed the discourse selecting past realizations as examples of the actual architectural practices, in order to become references to the way the architects deal with the present circumstances.

Siza had also a strong influence on his pupils, mainly when he was teaching the Construction course which operated together with the Architectural Design course, and other disciplines, favoring a holistic approach to architecture. The same can be said about Souto de Moura, to whom the architectural education could not be conceived without a strong cultural background and a solid knowledge of history and theory of architecture.

From them we learned a methodological approach to the project, where the use of drawing had a prominent role, in the recognition and understanding of a site, problem circumscription, and moreover in the process of definition of the architectural idea. Besides, we were clearly aware that we had a tradition to respect, having in mind Quatremère de Quincy's statement: 'nothing comes from nothing'.

That tradition had a very vivid moment during the carnation revolution, in 1974 (till 1976), where the school had the opportunity to redefine its bases, along with a direct intervention in real context. Teams of students and teachers worked together in housing programs for people dwelling in 'ilhas', densely populated areas with poor sanitation conditions in the backyards of traditional housing blocks. This was the well-known SAAL process and this pedagogical experience was later recognized as radical by Beatriz Colomina, and it actually was.

Ten years later, the school moved from São Lázaro, where the Fine Arts School remained, to Campo Alegre to the new facilities, as Faculty of Architecture. Since then, Siza's lesson is felt in each stone.

\section{REFERENCES}

Costa, Alexandre Alves (2013). 'Illustrated Fragments on the 'Porto School'. In Joelho 04. Coimbra: Edarq.

Costa, Ana Alves; COSTA, Ana Catarina, FERNANDEZ, Sergio (2019). Participatory City: Architecture and Democracy. S. Victor. Col. Operações SAAL 2. Lisboa: Editora Tinta da China. 
Fernandes, Eduardo Jorge (2010). A Escolha do Porto: Contributos para a actualização de uma ideia de Escola. Ph.D. Thesis. Guimarães: Universidade do Minho, Escola de Arquitectura.

Figueira, Jorge (2002). Escola do Porto: um mapa crítico. Coimbra: Edarq.

Moniz, Gonçalo Canto (2011). O Ensino Moderno da Arquitectura. A Reforma de 57 e a Escolas de Belas Artes em Portugal (1931-69). Ph.D. Thesis. Coimbra: Departamento de Arquitectura da Faculdade de Ciências e Tecnologia da Universidade de Coimbra.

Paulino, Raquel Geada (2013). ESBAPIFAUP. O Ensino da Arquitectura na Escola do Porto. Construção de um Projeto Pedagógico entre 1969 e 1984. Ph.D. Thesis. Porto: Faculdade de Arquitectura da Universidade do Porto.

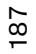

Portas, Nuno (1967). 'Sobre la Jóven Generación de Arquitectos Portugueses'. In Hogar y Arquitectura, no 68, p. 77-84. Siza, Álvaro (2009). 01 Textos. Porto: Civilização Editora.

Testa, Peter (1996). Álvaro Siza. Switzerland: Birkhäuser.

Wang, Wilfried (1988). Figures and Configurations: Álvaro Siza. Works 1985-88. Harvard: Emerging European Architects, Harvard University Graduate School of Design.

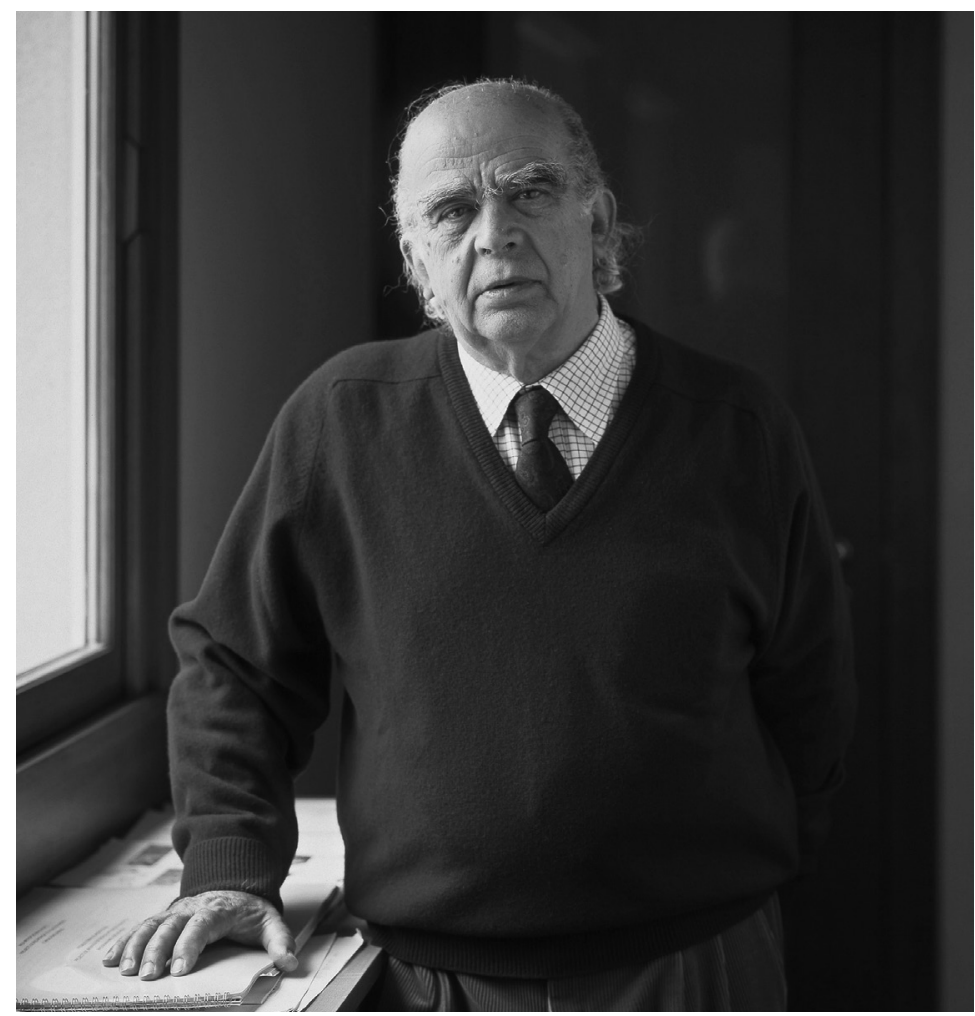

1: Fernando Távora. (C) Luís Ferreira Alves 


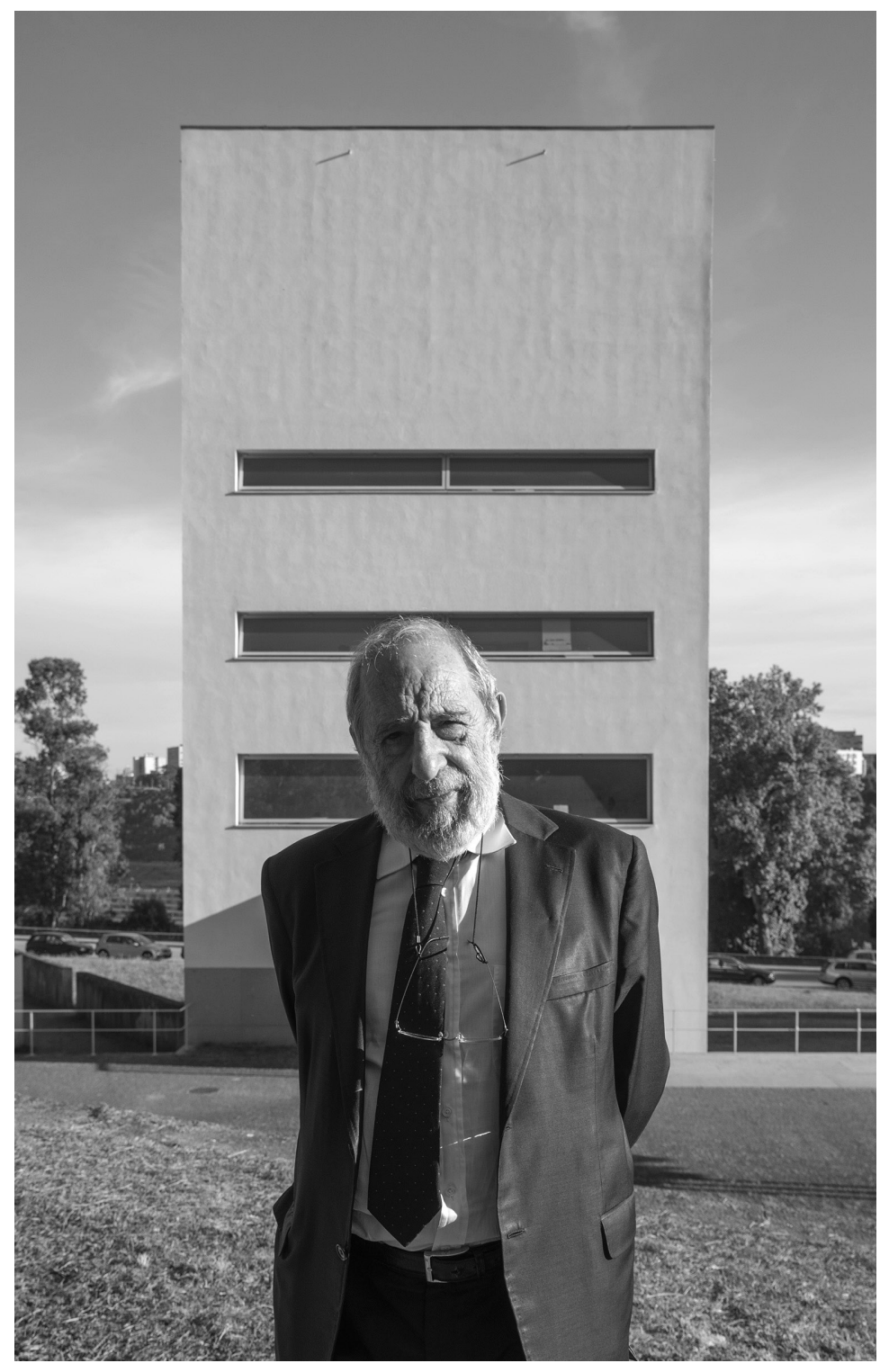

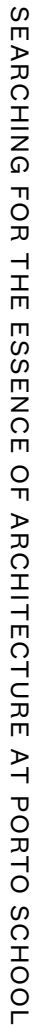

2: Álvaro Siza @ Egídio Santos 


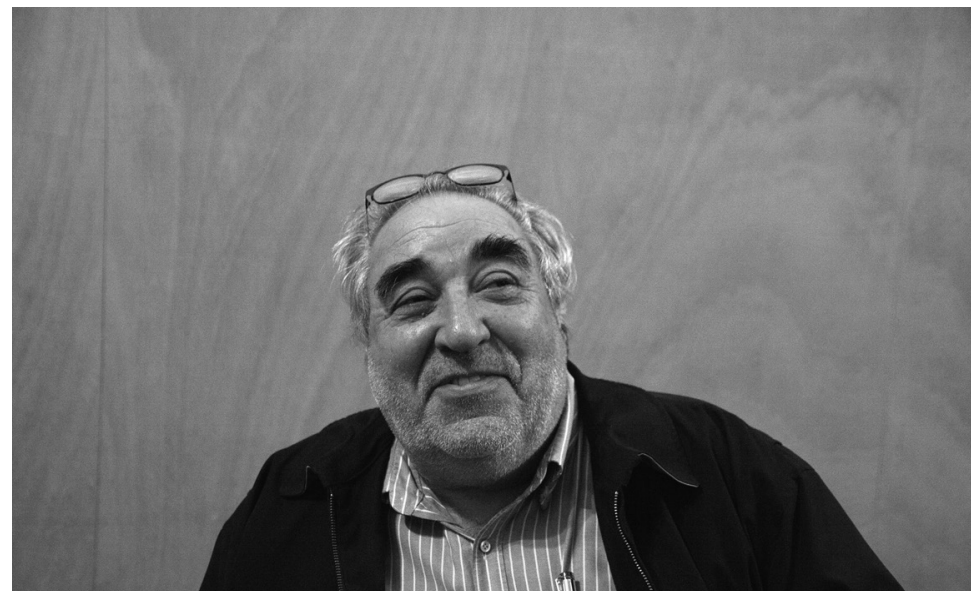

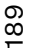

3: Eduardo Souto de Moura @ Clara Vale

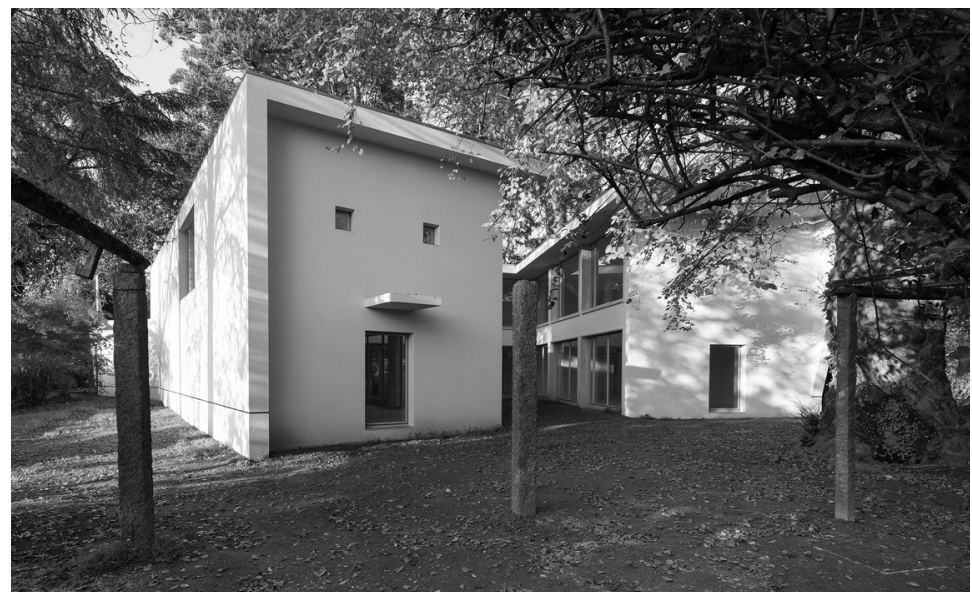

4: Carlos Ramos Pavilion (c) Egídio Santos

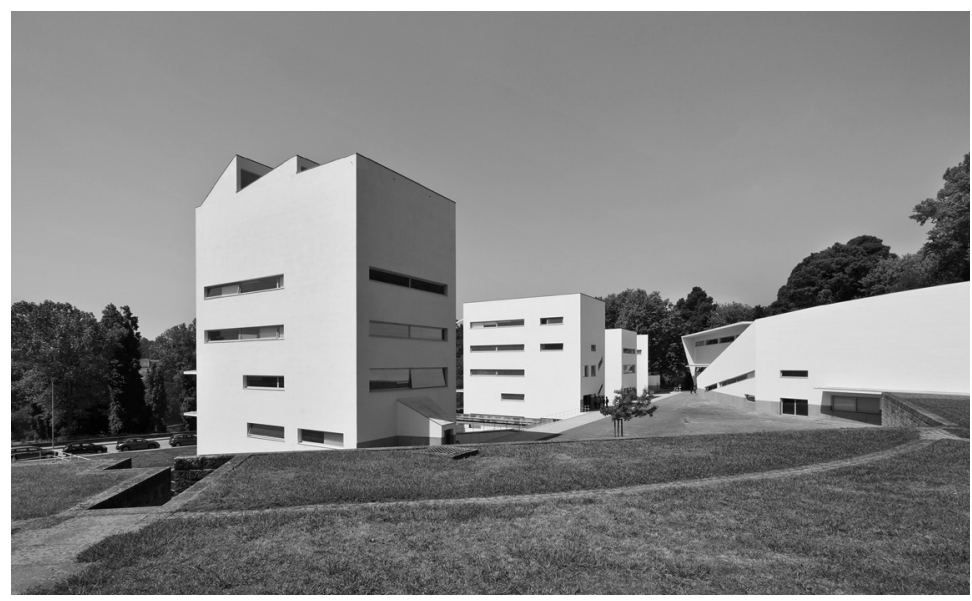

5: Faculty of Architecture at the University of Porto $\odot$ Luís Ferreira Alves 
POSTER

ABSTRACTS 